\title{
Metode Kritikan al-Kairanawi Terhadap Bible Berdasarkan Analisis Kitab Izhar al-Haq
}

\author{
Al-Kairanawi's Methods of Critique on Bible: An Analysis of 'Izhar al-Haq' \\ WAN HASLAN KHAIRUDDIN*, INDRIATY ISMAIL \& JAFFARY AWANG ${ }^{1}$
}

\begin{abstract}
Al-Quran is deemed to be the first text or charter which recognizes the existence of other religions in addition to asserting the truth of Islam and expose incoherent and the faults of otherwise. The facts set forth in the al-Quran, al-Kafirun 109: 1-6. Similarly, there are many verses in the Quran that deal with religions, whether samawi or wadha i religions. In presenting religions, the Quran highlight various methods of criticism such [i] method of comparison such as comparing the truth and falsehood or comparing between monotheism and polytheism, [ii] presents the falsehood faith based on historical method, [iii] method of arguing by demanding supported evidence, creed or faith from its believer. The diversity critical method of alQuran is a guide for scholars and Muslim intellectuals in dealing with propaganda of religions other than Islam through their works. The works Izhar al-Haq has written by Syeikh Rahmatullah al-Kairanawi (1818-1891) is subjected in this article. Discussion of this article focuses on al-Kairanawi's adaptation on the Quranic approach in criticizing the Bible; equation issues in Izhar al-Haq and the Quran; critical method by arguing and demanding textual evidences that are believed by the defendant. The methodology adopted in this study is content analysis and comparison between the approaches of the Izhar al-Haq and the Quran. Finally, the article concludes that alKairanawi approach in his Izhar al-Haq is accordance with the approach of the Quran in criticizing the Bible.
\end{abstract}

Keywords: Bible, Biblical criticism, Izhar al-Haq,al-Kairanawi, al-Quran

Islam merupakan agama yang mengajak dan memberi panduan kepada manusia dalam mencari akidah atau pemikiran benar dan logik berdasarkan pertimbangan hati dan juga akal. Al-Quran sebagai rujukan utamanya disifatkan sebagai panduan dalam menunjukkan jalan-jalan keselamatan serta kesejahteraan kepada insan yang mengikut petunjuknya, penyelamat yang dapat mengeluarkan insan dari gelap-gelita kekufuran kepada cahaya iman yang terang dan dengannya manusia akan sentiasa terpandu ke jalan yang lurus (al-Quran, al-Ma'idah 5:16). Bagi insan yang sering mentadabbur atau memikirkan isi kandungan ayat-ayat dan juga surahsurah al-Quran pasti akan mendapati kepelbagaian metode al-Quran dalam menghadapi bencana dan krisis yang dihadapi oleh manusia. Akidah yang batil, kepercayaan yang menyeleweng, akhlak yang rosak dan pelbagai lagi krisis kemanusiaan cuba dirungkai dan diselesaikan oleh Islam melalui al-Quran. Sebagai contoh, dalam menghadapi golongan yang tidak mempercayai kewujudan Tuhan iaitu ateis, al-Quran berbicara: "(Mengapa mereka tidak

\footnotetext{
${ }^{1}$ Wan Haslan Khairuddin*(Corresponding author), M.A., Lecturer at Dept. of Usuluddin, Akademi Islam, Kolej Universiti Islam Antarabangsa Selangor (KUIS), Bandar Seri Putra, 43600 BANGI, Selangor, Malaysia, E-mail: wanhaslan@kuis.edu.my, whk83@yahoo.com; Indriaty Ismail, Ph. D., Senior Lecturer at Dept. Of Theology and Philosophy, Faculty of Islamic Studies, Universiti Kebangsaan Malaysia, 43600 BANGI, Selangor, Malaysia, E-mail: indriaty@ukm.my; Jaffary Awang, Ph. D., Assoc. Professor at Dept. Of Theology and Philosophy, Faculty of Islamic Studies, Universiti Kebangsaan Malaysia, 43600 BANGI, Selangor, Malaysia, E-mail: jaffary@ukm.my, jaffaryawang@gmail.com.
} 
beriman?) Adakah mereka telah tercipta dengan tiada yang menciptanya, atau adakah mereka yang mencipta diri mereka sendiri? Adakah mereka yang mencipta langit dan bumi itu? (Sudah tentu tidak!) Bahkan mereka adalah orang-orang yang tidak meyakini (kebenaran apa yang mereka pernah mengakuinya)" (al-Quran, al-Thur 52:35-36). (Semua terjemahan ayat al-Quran dalam tulisan ini berdasarkan Tafsir Pimpinan ar-Rahman kepada Pengertian Al-Qur'an 2010).

Ketika menghadapi golongan yang berfahaman monoteisme iaitu tidak mentauhidkan Allah s.w.t, al-Quran menyatakan: "Kalau ada di langit dan di bumi tuhan-tuhan yang lain dari Allah, nescaya rosaklah pentadbiran kedua-duanya. Maka (bertauhidlah kamu kepada Allah dengan menegaskan): Maha Suci Allah, Tuhan yang mempunyai 'Arasy, dari apa yang mereka sifatka." (al-Quran, al-Anbiya' 21:22). Ketika berhadapan golongan yang rosak akhlaknya dalam berjual beli, al-Qur'an menegaskan: "Kecelakaan besar bagi orang-orang yang curang (dalam timbangan dan sukatan). Iaitu mereka yang apabila menerima sukatan (gantang cupak) dari orang lain mereka mengambilnya dengan cukup. Dan (sebaliknya) apabila mereka menyukat atau menimbang untuk orang lain, mereka kurangi" (al-Quran, al-Mutaffifin 83:1-3).

Dalam merungkai kesesatan akidah dan kepercayaan, al-Quran turut menggunakan pelbagai uslub atau kaedah dalam berbicara, berdialog dan berdebat. Agama Kristian adalah kelompok ketiga terbesar dan paling banyak dibicarakan al-Quran selepas kelompok Musyrikin (orang menyekutukan Allah s.w.t.) dan Yahudi (Kamar Oniah 2003). Berdasarkan kepada kajian dan analisis, A. Irwan Santeri menyatakan, terdapat sepuluh metode al-Quran dalam menolak kepercayaan penganut Kristian (A. Irwan 2004: 58-106).

Berdasarkan seruan umum al-Quran iaitu: "Serulah ke jalan Tuhanmu (wahai Muhammad) dengan hikmat kebijaksanaan dan nasihat pengajaran yang baik, dan berbahaslah dengan mereka (yang engkau serukan itu) dengan cara yang lebih baik; sesungguhnya Tuhanmu Dialah jua yang lebih mengetahui akan orang yang sesat dari jalanNya, dan Dialah jua yang lebih mengetahui akan orang-orang yang mendapat hidayah pertunjuk" (al-Quran, al-Nahl 16:125). Artikel ini akan menganalisis kitab Izhar al-Haq karya Syeikh Rahmatullah al-Kairanawi berkaitan pendekatan al-Quran dalam mengkritik Bible, bagaimana beliau mengadaptasi metod al-Quran dalam Izhar al-Haq, metode mengkritik dengan berhujah serta menuntut bukti dari dari nas-nas yang dipercayai defendan oleh al-Kairanawi.

\section{Latar Belakang Izhar al-Haq}

Izhar al-Haq ditulis oleh Syeikh Muhammad Rahmatullah bin Khalil atau Khalil al-Rahman alKairanawi al-Uthmani. Beliau dilahirkan pada awal Jamadilawal tahun $1233 \mathrm{H}$ iaitu bertepatan pada 9 Mac tahun 1818 M di Dariba Kalan, perkampungan Kairana, daerah Muzaffarnagar, Delhi, India. Oleh kerana masalah politik, beliau telah berhijrah ke Makkah pada tahun $1862 \mathrm{M}$. Beliau merupakan pengasas al-Madrasah al-Saulatiyyah di Makkah yang masyhur melahirkan tokoh-tokoh ulama dan mengajar di sana sehingga penghujung usianya. Beliau meninggal dunia ketika berusia 75 tahun, pada 22 Ramadhan tahun 1308H (1 Mei tahun $1891 \mathrm{M}$ ) dan dikebumikan di Maala atau al-Malat, Makkah (Malkawi 1405H: 31-48; Al-Nadawi 1990: 165176).

Syeikh Rahmatullah al-Kairanawi adalah keturunan sahabat mulia dan khalifah Islam ketiga iaitu Sayidina Uthman bin Affan radiallahuanhu. Berdasarkan salasilah keluarganya, beliau adalah lapis ke-35. Moyanganda beliau, Syeikh Abd. al-Rahman bin Abd. al-Aziz alSarakhsi adalah insan pertama menjejaki India dan menetap di Panipat ketika pemerintahan Sultan Mahmud al-Ghaznawi. Keluarga ini terus berkembang di India dan terkenal dengan kemuliaan, keilmuan, perubatan serta kedudukan yang tinggi di sisi para pemerintah Islam. Kebanyakan dari keluarga ini digelar dengan "al-Hakim" iaitu gelaran khusus kepada para tabib pemerintah ketika itu (Powell 1976: 50-53; Malkawi 1405 H: 29-32).

Penulisan Izhar al-Haq dianggap sebagai dokumentasi terhadap isu-isu perdebatan di antara Rahmatullah al-Kairanawi bersama Karl Gottlieb Pfander (1803-1865), seorang misionari German berpengaruh (Bennet 1996) dan pengarang Mizan al-Haq, buku propaganda terhadap Islam yang disifatkan amat merbahaya (Al-Kairanawi 2001: 24). Sejarah perdebatan 
berlangsung di Khan Abd. Al-Masih, Agra atau Akbar Abad pada hari Isnin, 11 dan 12 Rejab 1279 H (10 dan 11 April 1854). Namun, perdebatan dengan isu yang dirancang tidak sampai ke penghujungnya kerana permasalahan yang sengaja diadakan oleh Pfander. Al-Kairanawi dan Pfander hampir dipertemukan semula oleh Sultan Uthmaniyyah, Sultan Abd. Al-Aziz Khan untuk perdebatan kali kedua di Turki. Akan tetapi Pfander telah lari keluar dari Turki setelah mengetahui kedatangan al-Kairanawi adalah untuk dipertemukan dengan beliau (Al-Kairanawi 2001: 44).

Izhar al-Haq mula ditulis pada 16 Rejab 1280 H ketika Rahmatullah al-Kairanawi masih berada di Istanbul, Turki. Ianya siap ditulis pada penghujung Zulhijjah tahun yang sama sebagaimana catatan penulis di penghujung Izhar al-Haq (Al-Kairanawi 2001: 1365). Menurut Malkawi (Al-Kairanawi 2001: 1365), Izhar al-Haq ditulis dalam tempoh kurang enam (6) bulan atau dalam masa 160 hari. Al-Kairanawi dalam pendahuluannya telah menamakan sendiri kitab ini dengan "Izhar al-Haq". Beliau juga telah menamakan Syeikh Ahmad Zaini Dahlan, Mufti Makkah ketika itu sebagai insan yang mencadangkan penulisan Izhar al-Haq walaupun perlaksanaannya adalah selepas permintaan Sultan Uthmaniyyah ketika itu (Al-Kairanawi 2001: 45).

\section{Isi kandungan dan Perbahasan Kitab Izhar al-Haq}

Syeikh Rahmatullah al-Kairanawi dalam kata pendahuluan Izhar al-Haq menyatakan: "Aku menamakan kitab ini dengan Izhar al-Haq dan aku menyusun perbahasannya kepada mukadimah dan enam (6) bab" (Al-Kairanawi 2001: 8). Isi kandungan, perbahasan dan halaman kitab Izhar al-Haq berdasarkan edisi suntingan Muhammad Ahmad Muhammad Abd al-Qadir Khalil Malkawi (Al-Kairanawi 2001) adalah seperti jadual berikut:

\begin{tabular}{|l|l|c|c|}
\hline Perkara & Tajuk & Jilid & Halaman \\
\hline Mukadimah & $\begin{array}{l}\text { Penjelasan perkara-perkara yang perlu diberi perhatian } \\
\text { sebelum memulakan perbincangan. }\end{array}$ & 1 & $9-95$ \\
\hline Bab Pertama & Penjelasan berkaitan Perjanjian Lama dan Perjanjian Baru. & $1-2$ & $97-423$ \\
\hline Bab Kedua & Mensabitkan penyelewengan Bible & 2 & $425-625$ \\
\hline Bab Ketiga & Mensabitkan pemansuhan Bible & 3 & $641-680$ \\
\hline Bab Keempat & Mensabitkan kebatilan doktrin Triniti & 3 & $681-772$ \\
\hline Bab Kelima & Mensabitkan al-Quran sebagai kitabullah dan mukjizat & 3 & $773-987$ \\
\hline Bab Keenam & Mensabitkan kenabian Muhammad s.a.w. & 4 & $999-1367$ \\
\hline
\end{tabular}

Penyusunan Isi kandungan dan tajuk perbahasan Izhar al-Haq karya al-Kairanawi mempunyai signifikannya tersendiri. Penulis Izhar al-Haq dilihat terlebih dahulu membincangkan isu penyelewengan Bible, ini kerana apabila sabit atau terbukti kenyataan ini benar maka tidak syak lagi kemungkinan Bible boleh dimansuhkan dengan kitab suci yang lain. Seterusnya dibincangkan persoalan Triniti dan ketuhanan Isa a.s. kerana penganut Kristian mendakwa mereka meyakini akidah ini berpandukan kitab suci mereka. Apabila terbukti penyelewengan dan pemansuhan Bible maka akidah ini jelas tidak mempunyai asas yang kukuh. Seterusnya, tiada lagi penghujahan penganut Kristian untuk tidak mengakui kebenaran Nabi Muhammad s.a.w. apabila terbukti al-Quran itu sebagai mukjizat dan terbukti bahawa Baginda merupakan rasul yang diutuskan (Al-Kairanawi 2001: 88-89). Izhar al-Haq boleh dianggap sebagai masterpiece Rahmatullah al-Kairanawi. Ini kerana Izhar al-Haq telah menghimpunkan segala isi dan isu perbincangan karya-karya terawal beliau seperti Izalah al-Shukuk (1268H), Izalah al-Auham (1269H), al-I'jaz al-Aisawi (1271H), Ahsan al-Hadith fi Ibtal al-Tathlith (1271H) dan lain-lain (Powell 1976: 50-53; Al-Kairanawi 2001: 18-21). Bagi penganut Kristian, penyebaran Izhar al-Haq dan edisi terjemahannya amat digeruni sehingga disifatkan: "Sekiranya manusia terus membaca buku ini nescaya agama Kristian tidak akan berkembang maju di dunia" (Al-Nadawi 1990: 172). 


\section{Pendekatan Al-Quran dalam Mengkritik Bible}

Kajian di bawah tajuk ini tertumpu kepada pendekatan al-Quran dalam mengkritik Bible dan adaptasi al-Kairanawi dalam karyanya Izhar al-Haq. Sebagaimana yang telah dinyatakan, alQuran telah menggunakan pelbagai metode dalam mengkritik Bible. A. Irwan Santeri (2004: 58106) merumuskan beberapa metode yang diguna pakai al-Quran, antaranya: metode penceritaan atau persejarahan; metode kias atau analogi; metode mensabitkan pendustaan dan menuntut kebenarannya; metode membatalkan dakwaan dan mensabitkan dakwaan sebaliknya; dan metode berhujah dan menuntut bukti dari nas-nas yang dipercayai defendan. Namun, artikel ini hanya akan membincangkan metode penceritaan atau persejarahan dan metode kiasan.

\section{Metode Penceritaan atau Persejarahan}

Penceritaan merupakan pendekatan utama al-Quran dalam menyatakan pelbagai perkara. Sekiranya diperhalusi, penceritaan berkenaan Nabi Isa a.s. atau "Yesus Kristus" (menurut nama dalam Alkitab Berita Baik terbitan The Bible Society of Malaysia 2001) berbanding penceritaan nabi-nabi lain adalah yang terbanyak diceritakan al-Quran. Penceritaan Nabi Isa a.s. bermula semenjak dilahirkan sehinggalah Baginda bertemu Allah s.w.t. di akhirat kelak. Sebanyak 25 kali dan 19 surah al-Quran menceritakan kisah Nabi Isa a.s. Pengulangan yang banyak ini menunjukkan pentingnya subjek atau isi kandungan perbahasan. Al-Quran dengan pendekatan penceritaan atau persejarahan seolah cuba menyingkap isu, perkara dan fakta sebenar berkaitan Nabi Isa a.s. yang telah disembunyikan oleh penganut agama Kristian (A. Irwan 2004: 59-62). Sebagai contoh, al-Quran menyatakan dalam surah Maryam (19:37): "Kemudian, golongan-golongan (dari kaumnya) itu berselisihan sesama sendiri. Maka kecelakaanlah bagi orang-orang kafir (yang berselisihan) itu, dari apa yang disaksikan pada hari yang besar huruharanya.". Perselisihan yang dimaksudkan pada ayat ini ialah pernyataan Yahudi mengatakan bahawa Nabi Isa a.s. itu sebagai ahli sihir, kumpulan atau mazhab Kristian Jacobites mengatakan Baginda sebagai Tuhan, Nestorians mengatakan sebagai Anak Tuhan dan Melkites mengatakan sebagai spirit atau ruh atau Ruhulkudus (i.i. roh suci iaitu entiti ketiga dalam keesaan Tuhan mengikut ajaran Kristian) (Thomas 1992: 67; A. Irwan 2004: 72).

Al-Kairanawi dilihat mengadaptasikan metode penceritaan atau persejarahan di awal perbahasan Izhar al-Haq ketika menjelaskan bab pertama bertajuk: "Penjelasan berkaitan Perjanjian Lama dan Perjanjian Baru". Perbahasan tajuk-tajuk di bawah bab ini diperincikan kepada empat fasal seperti jadual berikut:

\begin{tabular}{|l|l|}
\hline Fasal & \multicolumn{1}{|c|}{ Tajuk } \\
\hline Fasal Pertama & Penjelasan nama-nama dan bilangan Bible. \\
\hline Fasal Kedua & Penjelasan tiada sanad bersambung bagi Bible. \\
\hline Fasal Ketiga & $\begin{array}{l}\text { Penjelasan Bible dipenuhi dengan kontradiksi (al-ikhtilafat) dan kesalahan } \\
\text { (al-aghlatat). }\end{array}$ \\
\hline Fasal Keempat & $\begin{array}{l}\text { Penjelasan tiada ruang bagi penganut Kristian untuk mendakwa bahawa Bible ditulis } \\
\text { dengan ilham. }\end{array}$ \\
\hline
\end{tabular}

Al-Kairanawi pada fasal pertama menceritakan nama-nama dan bilangan-bilangan kitab yang terdapat di dalam Perjanjian Lama dan Perjanjian Baru atau Bible berdasarkan sejarah yang berlaku kepada penganut dan gereja Kristian. Daripada 47 kitab Perjanjian Lama, sebanyak 38 kitab sahaja yang disepakati kebenarannya oleh kebanyakkan penganut awal Kristian. Ada pun bakinya diperselisihkan kebenarannya. Manakala kitab-kitab di dalam Perjanjian Baru, hanya 20 dari 27 kitab disepakati. Perselisihan ini terus berlaku dalam sejarah Kristian sehinggalah wujud pada hari ini perbezaan naskhah Bible yang diiktiraf oleh mazhab Katolik dan Protestan (Al-Kairanawi 2001: 98-108). 
Pada fasal kedua, al-Kairanawi ketika membahaskan sanad kitab-kitab Perjanjian Lama iaitu [1] Surat Yakobus atau James, [2] Surat Petrus yang Kedua atau 2 Peter, [3] Surat Yohanes yang Kedua atau 2 John, [4] Surat Yohanes yang Ketiga atau 3 John, [5] Surat Yudas atau Jude, [6] Surat kepada Orang Ibrani atau Hebrews dan [7] Wahyu kepada Yohanes atau Revelation. Beliau mengulas sejarah yang berlaku dengan mengatakan bahawa enam (6) kitab pertama di atas diragui dan ditolak ketika pertemuan tokoh-tokoh Kristian pada tahun 363 Masihi, kemudian pada pertemuan tahun 364 Masihi mereka mengiktirafnya. Ada pun kitab ketujuh iaitu Wahyu kepada Yohanes atau Revelation terus diragui dan ditolak sehinggalah pertemuan tokoh-tokoh Kristian pada tahun 397 M. Berdasarkan metode penceritaan atau persejarahan, al-Kairanawi mengemukakan hujah kecelaruan tokoh-tokoh Kristian dengan mengatakan bahawa Bible versi terjemahan Yunani merupakan edisi yang diperakui semenjak zaman hawariun (i.i. para sahabat Nabi Isa a.s.) sehinggalah kurun ke-15. Adapun Bible versi terjemahan Ibrani atau Hebrew (i.i. bahasa Yahudi kuno) tidak diiktiraf dan dianggap diselewengkan. Namun, beberapa waktu setelah munculnya aliran dan mazhab Protestan keadaaan menjadi sebaliknya, edisi yang diperakui diragui dan edisi yang diragui diperakui (Al-Kairanawi 2001: 165-166).

\section{Metode Kias atau Analogi}

Menurut Kamus Dewan (2007: 52, 786), kias dan analogi bermaksud perbandingan dengan contoh yang telah ada atau dengan hal yang telah berlaku. Atau perbandingan dengan memperlihatkan ciri-ciri persamaan daripada contoh yang telah ada atau dengan hal yang telah berlaku. Al-Quran banyak menggunakan metode ini dalam menyampaikan mesej-mesej tertentu. Sebagai contoh, al-Quran menegaskan bahawa mustahil bagi mereka yang kufur dan mendustakan ayat-ayat Allah untuk masuk syurga dengan kiasan dan analogi "mereka tidak akan masuk Syurga sehingga unta masuk ke dalam lubang jarum" (al-Quran, al-A raf 7:40). AlQuran turut menggunakan pendekatan dan metode kias dan analogi dalam menyanggah kepercayaan penganut Kristian. Sebagai contoh, para penganut Kristian meyakini Nabi Isa a.s. sebagai tuhan atau anak tuhan kerana berhujah bahawa Baginda dilahirkan tanpa bapa. Dalam membuktikan kedangkalan hujah yang dinyatakan, al-Quran mendatangkan kias dan analogi berikut: "Sesungguhnya perbandingan (kejadian) Nabi Isa di sisi Allah adalah sama seperti (kejadian) Nabi Adam. Allah telah menciptakan Adam dari tanah lalu berfirman kepadanya: "Jadilah engkau!" maka menjadilah ia." (al-Quran, Ali `Imran 3:59). Ayat ini memberi kefahaman; sekiranya Nabi Isa a.s. dipertuhankan kerana dilahirkan tanpa bapa, maka bagaimanakah kedudukan Nabi Adam a.s. yang dilahirkan tanpa ibu dan bapa? (A. Irwan 2004: 76-78).

Al-Kairanawi dalam penghujahan terhadap doktrin Triniti mendatangkan tiga bentuk hujah: bantahan terhadap doktrin Triniti berdasarkan logik akal; bantahan terhadap doktrin Triniti berdasarkan Bible; dan bantahan terhadap dakwaan ketuhanan Isa a.s. berdasarkan Bible. Penggunaan metode kias dan analogi dilihat banyak digunakan al-Kairanawi dalam "bantahan terhadap doktrin Triniti berdasarkan logik akal". Sebagai contoh, penganut Kristian mengatakan Tauhid dan Trinti adalah hakikat yang sama. Seumpama mengatakan tiga itu satu dan satu itu tiga. Sedangkan, tiga itu adalah dari satu, satu dan satu. Satu pula bukanlah dari satu, satu dan satu. Al-Kairanawi mendatangkan analogi, sebuah batu yang diletakkan di sisi seorang manusia, maka dari keduanya ( batu dan manusia) tidak menghasilkan entiti yang satu. Begitulah keadaannya unsur-unusr Triniti iaitu Tuhan, Anak Tuhan dan Ruhulkudus tidak mungkin menghasilkan entiti yang satu. Penganut Kristian mengatakan bahawa Nabi Isa a.s. bersatu dengan unsur ketuhanan sehingga menjadikan Baginda sebagai Anak Tuhan. Ianya ibarat penyatuan warna dengan objek. Al-Kairanawi mempersoalkan, munculnya warna kerana adanya objek menjelaskan bahawa adanya warna kerana adanya objek. Kesimpulannya, unsur ketuhanan hanyalah unsur tempelan, bagaimana mungkin merubah kedudukan Nabi Isa a.s. sebagai Anak Tuhan? (Al-Kairanawi 2001: 725-728). 


\section{Kritikan Al-Quran Terhadap Bible dalam Kitab Izhar al-Haq}

Sebagaimana yang telah dinyatakan, Izhar al-Haq membincangkan lima (5) isu utama yang sering menjadi perbalahan di antara Islam dan Kristian. Tiga daripada lima isu itu ialah: penyelewengan (tahrif) Bible; pemansuhan (naskh) Bible; dan kebatilan doktrin Triniti. Ketigatiga isu ini merupakan perbincangan utama al-Quran terhadap penganut-penganut Kristian secara umum (Jaffary 1991: 26-31).

\section{Penyelewengan Bible}

Penyelewengan yang dimaksudkan di sini ialah mengubah suai atau membuat perubahan pada teks asal Bible supaya menjadi sesuai dengan sesuatu keadaan, keperluan, kegunaan dan sebagainya (Kamus Dewan 2007: 1752; e-Kamus 2007; al-Mu'jam al-Asasi al-'Arabi. t.th.: 307). Penyelewengan Bible dijelaskan oleh al-Quran dalam pelbagai bentuk (Mutei 2007: 209-210). Pertama, istilah taktumuna iaitu penyelewengan dengan menyembunyikan kebenaran. Surah alBaqarah (2:146) menjelaskan: "Dan sesungguhnya sebahagian dari mereka berusaha menyembunyikan kebenaran itu, sedang mereka mengetahui (salahnya perbuatan yang demikian)". Kedua, istilah takhfuna iaitu menyembunyikan kebenaran yang terkandung dalam teks asal. Surah al-Mai'dah (5:15) menjelaskan: "Wahai Ahli Kitab! Sesungguhnya telah datang kepada kamu Rasul Kami (Muhammad, s.a.w) dengan menerangkan kepada kamu banyak dari (keterangan-keterangan dan hukum-hukum) yang telah kamu sembunyikan dari Kitab Suci, dan ia memaafkan kamu (dengan tidak mendedahkan) banyak perkara (yang kamu sembunyikan). Sesungguhnya telah datang kepada kamu cahaya kebenaran (Nabi Muhammad) dari Allah, dan sebuah Kitab (Al-Quran) yang jelas nyata keterangannya.". Ketiga, istilah yuharrifuna iaitu mengubah suai sesuai dengan kehendak dan keperluan. Surah al-Mai'dah (5:13) menjelaskan: "Mereka sentiasa mengubah Kalimah-kalimah (yang ada di dalam kitab Taurat dengan memutarnya) dari tempat-tempatnya (dan maksudnya) yang sebenar, dan mereka melupakan (meninggalkan) sebahagian dari apa yang diperingatkan mereka mereka dengannya.". Keempat, istilah baddala iaitu menukar sesuatu dengan sesuatu yang lain. Al-Acraf (7:162) menjelaskan: "Maka orang-orang yang zalim di antara mereka menukarkan perintah itu dengan perkataan yang tidak dikatakan kepada mereka.".

Al-Kairanawi dalam bab kedua Izhar al-Haq bertajuk: "Mensabitkan penyelewengan (tahrif) Bible" membahaskan tiga bentuk penyelewengan yang berlaku: tabdil atau penukaran perkataan atau ungkapan yang terdapat dalam karya asli; ziyadah atau penambahan perkataan atau ungkapan yang tidak terdapat dalam karya asli, dan; nuqsan atau pengurangan perkataan ]atau ungkapan yang terdapat dalam karya asli. Metode perbandingan teks daripada pelbagai naskhah Bible diguna pakai beliau dalam perbahasan ini (Al-Kairanawi 2001: 425-541).

\section{Pemansuhan Bible}

Naskh atau abrogation atau pemansuhan yang dimaksudkan di sini ialah pembatalan dan penghapusan autoriti dan kesahan isi kandungan Bible kerana turunnya al-Qur'an. Isu pemansuhan ini dinyatakan dalam Surah al-Baqarah (2:106): "Apa sahaja ayat keterangan yang Kami mansukhkan (batalkan), atau yang Kami tinggalkan (atau tangguhkan), Kami datangkan ganti yang lebih baik daripadanya, atau yang sebanding dengannya. Tidakkah engkau mengetahui bahawasanya Allah Maha Kuasa atas tiap-tiap sesuatu?". Al-Kairanawi dalam bab ketiga Izhar al-Haq bertajuk: "Mensabitkan pemansuhan (naskh) Bible" membahaskan dua bentuk pemansuhan yang berlaku: naskh atau pemansuhan daripada syariat baru seorang nabi ke atas syariat nabi sebelumnya, dan; naskh atau pemansuhan daripada syariat baru seorang nabi ke atas syariatnya sendiri (Al-Kairanawi 2001: 647-648). Al-Kairanawi dilihat membawa contoh-contoh daripada bahagian pertama naskh atau pemansuhan yang berlaku sebanyak 21 contoh dan daripada bahagian kedua sebanyak 12 contoh. Metodologi yang digunapakai al- 
Kairanawi dalam perbahasan ini ialah metode perbandingan teks dan kandungan Bible (AlKairanawi 2001: 641-680).

Sebagai contoh daripada bahagian pertama naskh atau pemansuhan yang berlaku ialah hukum perkahwinan yang berlaku dalam syariat para nabi terdahulu. Pada zaman Nabi Adam a.s. dibolehkan perkahwinan sesama adik beradik seibu dan sebapa. Adapun pada zaman Nabi Ibrahim, menurut Genesis atau Kejadian (20:12), perkahwinan hanya dibolehkan sesama adik beradik sebapa. Manakala pada syariat Nabi Musa a.s., menurut Leviticus atau Imamat (18:9), (20:17) dan Numbers atau Bilangan (27:22), hukum perkahwinan berubah di mana perkahwinan sesama adik beradik sama ada seibu dan sebapa atau sebapa atau seibu adalah diharamkan dan terkutuk. Bahkan ianya diangap zina dan boleh dihukum bunuh.

\section{Tathlith atau Triniti}

Tathlith atau Triniti adalah antara isu lain yang turut diperbahaskan al-Quran terhadap penganut Kristian. Terdapat dua ayat utama al-Quran yang menyebutkan Triniti. Pertama, alNisa' (4:11) dan kedua al-Maidah 5:73. Penganut Kristian mengatakan Tuhan itu satu tetapi terdiri daripada tiga (3) entiti iaitu Tuhan, Anak Tuhan dan Ruhulkudus. Istilah "Triniti" pada hakikatnya tidak terdapat di dalam Bible, tetapi penganut Kristian mengatakan terdapat isyarat yang menunjukkan pegangan mereka ini. Seseorang tidak dianggap penganut Kristian kecuali setelah beriman dengan doktrin Triniti (A. Irwan 2004: 49). Al-Kairanawi telah membahaskan isu Trinit dalam Izhar al-Haq di bawah bab keempat bertajuk: "Mensabitkan kebatilan doktrin Triniti".

\section{Berhujah dan Menuntut Bukti dari Nas yang Dipercayai Defendan}

Metode berhujah dan menuntut bukti dari nas-nas yang dipercayai defendan adalah salah satu daripada metode al-Quran dalam dialog, perbahasan, debat dan kritikan terhadap kepercayaan penganut agama lain khususnya Kristian. Metode ini dinyatakan al-Quran dalam al-Baqarah (2:111): "Dan mereka (Yahudi dan Nasrani) berkata pula: "Tidak sekali-kali akan masuk Syurga melainkan orang-orang yang beragama Yahudi atau Nasrani". Yang demikian itu hanyalah angan-angan mereka sahaja. Katakanlah (wahai Muhammad): "Bawalah kemari keteranganketerangan yang (membuktikan kebenaran) apa yang kamu katakan itu, jika betul kamu orangorang yang benar.". Metode ini turut disebutkan dalam surah al-Anbiya' (21:24), al-Naml (27:64); al-Qasas (28:75). Al-Kairanawi telah mengadaptasikan pendekatan dan metode alQuran ini dalam Izhar al-Haq dalam pelbagai bentuk. Kajian dan tinjauan awal merumuskan tiga bentuk pendekatan yang dibawa oleh al-Kairanawi iaitu pembawaan sejarah yang diketahui dan diyakini penganut Kristian; pembawaan nas-nas dari naskhah Bible pelbagai versi dan terjemahan, dan; pembawaan tafsiran dan kata-kata tokoh Kristian berautoriti.

Pertama, pembawaan sejarah yang diketahui dan diyakini penganut Kristian oleh alKairanawi boleh dilihat ketika beliau menjelaskan sejarah kedudukan tujuh kitab dalam Perjanjian Baru yang diperselisihkan penganut Kristian. Singkapan peristiwa dan perbincangan yang berlaku oleh tokoh Kristian dalam Council of Nicaea (325M), Council of Laodicea (364M) dan Council of Carthage (397M), Council of Florence (1447M), Council of Trent (1545M) dan sebagainya. Sejarah Kristian membuktikan bahawa tokoh-tokoh Kristian itu sendiri tidak begitu yakin dengan kedudukan kitab-kitab dalam Bible berdasarkan keputusan-keputusan yang sering berubah (Al-Kairanawi 2001: 105-108).

Kedua, pembawaan nas-nas dari naskhah Bible pelbagai versi dan terjemahan sebagaimana catatan al-Kairanawi adalah daripada terjemahan lima kitab Nabi Musa a.s. (1848) serta terjemahan Perjanjian Lama dan Perjanjian Baru yang dicetak oleh William Watts, terjemahan golongan Protestan dengan mohor diraja bagi tahun 1819, 1830, 1835 dan 1848, terjemahan Perjanjian Lama dan Perjanjian Baru Roman Katolik tahun 1840 Masihi (AlKairanawi 2001: 10-11). Peyunting Izhar al-Haq, Muhammad Abd. Al-Qadir Malkawi telah menyenaraikan versi rujukan Bible yang dijadikan rujukan al-Kairanawi dalam Izhar al-Haq 
mencecah 32 buah iaitu 13 buah dalam Bahasa Arab, 8 buah dalam Bahasa Farsi, 6 buah dalam Bahasa India dan 5 buah dalam Bahasa English (Al-Kairanawi 2001: 83).

Ketiga, pembawaan tafsiran dan kata-kata tokoh Kristian berautoriti oleh al-Kairanawi sebagaimana catatan beliau adalah daripada tafsiran Perjanjian Lama dan Perjanjian Baru oleh Adam Clark (1851), tafsiran Houran (1851), tafsiran Henry (t.th.), tafsiran Ardanr (1827), tafsiran Douly serta Richard Mint (1848) dan tafsiran Harsley (t.th.) (Al-Kairanawi 2001: 1011). Sebagai rumusan kepada perbincangan, al-Quran merupakan kitab panduan, petunjuk, tiada sebarang syak padanya (tentang datangnya dari Allah dan kesempurnaannya) (al-Quran, al-Baqarah 2:2), pembeza di antara kebenaran dan kebatilan serta peringatan bekalan khalik kepada makhluk (al-Quran, al-Furqan 25:1). Bagi mereka yang menjadikan al-Quran sebagai rujukan utama dalam kehidupan pastinya selamat dalam kehidupannya di dunia dan akhirat. AlQuran dengan kepelbagaian pendekatan dan metodologinya adalah penyelamat umat dari terjerumus kepada akidah dan ajaran sesat, budaya negatif, gejala sosial dan sebagainya. Mutakhir, dialog antara agama menjadi medium dan pilihan utama semua penganut agama di seluruh dunia. Malaysia sebagai sebuah negara yang mengamalkan demokrasi dan mempunyai berbilang bangsa serta agama tidak terkecuali, dialog antara agama merupakan jalan terbaik dan berhikmah sebagai usaha dakwah kepada bukan Islam. Di samping itu, ianya juga merupakan sebahagian usaha untuk menangani isu murtad dan isu penyelewengan agama. Merujuk kepada panduan al-Quran, usaha dakwah mestilah dengan hikmat kebijaksanaan, nasihat pengajaran yang baik, dan perbahasan atau perdebatan dengan cara yang lebih baik (alQuran, al-Nahl 16:125).

Selain daripada petunjuk umum di atas, al-Quran turut memaparkan pelbagai metode dalam berinteraksi dan berbahas semasa penganut agama lain. Antara metode yang diguna pakai al-Quran: metode penceritaan atau persejarahan; metode kias atau analogi; metode mensabitkan pendustaan dan menuntut kebenarannya; metode membatalkan dakwaan dan mensabitkan dakwaan sebaliknya; dan metode berhujah dan menuntut bukti dari nas-nas yang dipercayai defendan (A. Irwan 2004: 58-106). Kepelbagaian metode al-Quran ini menjadi panduan dalam dialog, debat dan penulisan para ulama Islam.

Izhar al-Haq karangan Syeikh Rahmatullah al-Kairanawi merupakan karya mutakhir yang dianggap lengkap memperbahaskan isu-isu utama yang menjadi perbalahan IslamKristian. Ianya adalah dokumentasi perdebatan yang berlaku di antara Rahmatullah alKairanawi bersama seorang missionari German, Karl Gottlieb Pfander (1803-1865). Izhar alHaq amat berpengaruh sehinggakan Ahmad Deedat (1918- 2005) (t.th.: 17-20; Al-Kairanawi 2003: xv-xx) memperakui, Izhar al-Haq benar-benar mengubah hidup beliau, membantunya dalam melaksanakan usaha dakwah dan mempertahankan Islam. Analisis terhadap Izhar al-Haq memperlihatkan pengadaptasian pendekatan al-Quran oleh al-Kairanawi dalam kritikan beliau ke atas Bible. Isu Tahrif atau penyelewengan, Naskh atau pemansuhan dan Tathlith atau Triniti adalah isu-isu utama yang dibincangkan al-Qur'an turut dibincangkan oleh al-Kairanawi. AlKairanawi dalam perbahasannya terhadap isu-isu yang dibawa telah menggunakan pendekatan dan metode al-Quran seperti metode penceritaan atau persejarahan; metode kias atau analogi; dan metode berhujah dan menuntut bukti dari nas-nas yang dipercayai defendan. Kesimpulannya, pendekatan kritis Izhar al-Haq jelas menepati pendekatan al-Quran.

\section{References}

\section{Al-Quran.}

Tafsir Pimpinan ar-Rahman kepada Pengertian Al-Qur'an. 2010. Kuala Lumpur: Darul Fikir. Alkitab Berita Baik. 2001. Selangor: The Bible Society of Malaysia.

A. Irwan Santeri. 2004. Manhaj al-Quran fi Mujadalah al-Nasara. Disertasi Sarjana. Universiti Islam Antarabangsa Malaysia.

Bennet, Clinton. 1996. The legacy of Karl Gottlieb Pfander. International Bulletin of Missionary Research 20(2): 76-80. 
Deedat, Ahmad. t.th. Hadhihi Hayati: Sirati wa Masirati. Ashraf Muhammad al-Wahsy (pnys.) Cairo: Dar al-Fadhilah.

e-Kamus. 2007. Version 5.02.07. t.tp.: Alaf Teras.

Jaffary Awang. 1991. Polemik Islam-Kristian di Agra: Peranan Maulana Rahmat Allah Kairanawi. Latihan Ilmiah Sarjana Muda. Universiti Kebangsaan Malaysia.

al-Kairanawi, Muhammad Rahmatullah. 2001. Izhar al-Haq. Muhammad Ahmad Muhammad Abd al-Qadir Khalil Malkawi (pnyt.). Jil. 1, 2, 3 \& 4. Egypt: Dar al-Hadis.

Kamar Oniah Kamaruzaman. 2003. Early Muslim Scholarship in Religionswissenchaft: The Work and Contributions of Abu Rayhan Muhammad Ibn Ahmad al-Biruni. Kuala Lumpur: International Institute of Islamic Thought and Civilization (ISTAC).

Kamus Dewan. 2007. Edisi ke-4. Kuala Lumpur: Dewan Bahasa dan Pustaka.

Malkawi, Muhammad Ahmad Muhammad Abd al-Qadir Khalil. 1405H. Al-Munadharah al-Kubra bayna al-Syeikh Rahmatullah wa al-Duktur al-Qissis Fandar. Riyadh : Dar Ibn Taymiyyah li al-Nashr wa al-Tauzi wa al-Ilam.

al-Mu'jam al-Asasi al-'Arabi. t.th. t.pt.: Al-Munazzamah al-Arabiyyah li al-Tarbiyyah wa alThaqafah wa al-'Ulum.

Mutei, J. M. 2007. The Bible: Classical And Contemporary Muslim Attitudes and Exegesis. Evangelical Review of Theology 31(3): 207-220.

Al-Nadawi, Abu al-Hassan Ali al-Husayni. 1410H/1990. Shakhsiyyat wa Kutub. Damascus: Dar al-Qalam.

Powell,A.A. 1976. Maulana Rahmat Allah Kairanawi and Muslim-Christian Controversy in India in the Mid-19th Century. Journal of the Royal Asiatic Society of Great Britain \& Ireland 108(1): 42-63.

Thomas, D. R. 1992. Anti Christian Polemic in Early Muslim Islam: Abu Isa al-Warraq's Againt the Trinity. New York: The University of Cambridge. 